

\section{Sumário}

I. Crônicas do Direito Internacional ...............................................1

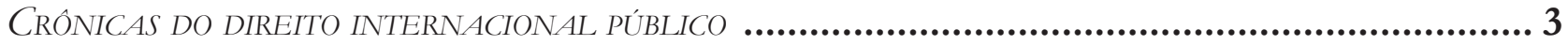

A resolução 2272 (2016) do Conselho de Segurança das Nações Unidas - O POSICIONAMENTO DA ONU FACE ÀS ALEGAÇÕES DE ABUSO E EXPLORAÇÃo SEXUAL POR SUAS

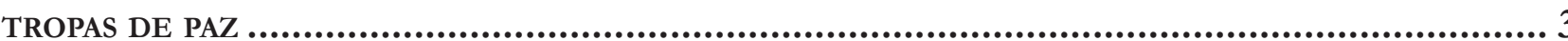

Sarah Dayanna Lacerda Martins Lima

CRÓNICAS DE DiREITo INTERNACIONAL PRIVADO...................................................................

Nadia de Araujo, Marcelo De Nardi, Gustavo Ribeiro, Fabrício Polido e Inez Lopes

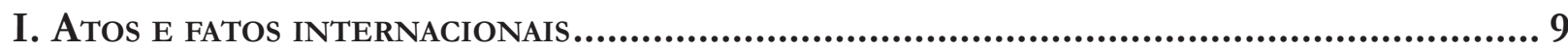

Crônica 1. Novidades de 2017 SObRE CIRCulaÇÃo faCilitada DE SENTENÇAS ESTRANGEIRAS 9

Crônica 2: O Direito Transnacional e os episódios das Carnes.........................................16

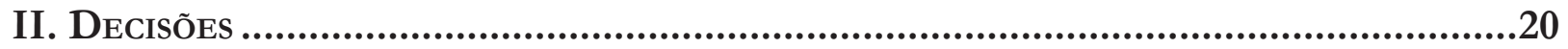

Crônica 3: A Irresistível ForÇa da ORDEM PÚblica E A HOMOLOGaÇÃo DE SENTENÇAS

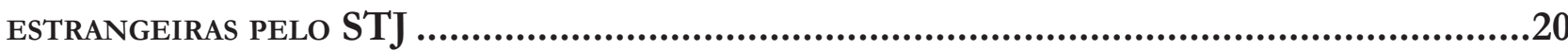

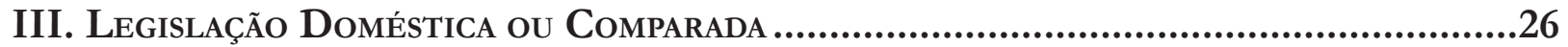

Crônica 4 - Dignidade da pessoa humana e mudança de paradigma da Lei de Migração

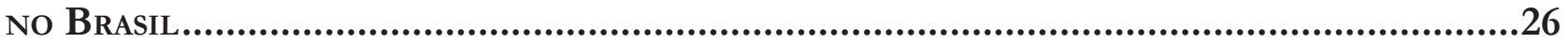

II. Dossiê especial: Direito Internacional dos InVEstimentos ................35

Non-adjudicatory State-State Mechanisms in Investment Dispute Prevention and Dispute Settlement: Joint Interpretations, Filters and Focal Points 
Mapping the Duties of Private Companies in International Investment Law .50 Nitish Monebhurrun

LA LÉGALITÉ DE L'INVESTISSEMENT DEVANT L'ARBITRE INTERNATIONAL: À LA RECHERCHE D'UN POINT D'ÉQUILIBRE .73 Hervé Ascensio

Host STATES AND STATE-STATE INVESTMENT ARBITRATION: STRATEGIES AND CHALlENGES......81 Murilo Otávio Lubamdo de Melo

Right to Regulate, Margin of Appreciation and Proportionality: Current Status in Investment Arbitration in Light of Philip Morris V. Uruguay. .95 Giovanni Zarra

Investments on Disputed Territory: Indispensable Parties and Indispensable Issues....122 Peter Tzeng

The Influence of General Exceptions on the Interpretation of National

Treatment in INTERNATIONAL INVESTMENT LAW. 140 Louis-Marie Chauvel

UMA PRoposta de REFleXão SObRe os ACFIs: Até QUE PONTO O TRATAMENTo de NAÇão MAIS FAVORECIDA PODE MINAR A ESTRATÉGIA POLÍTICA QUE OS EMBASA? 160

Michelle Ratton Sanchez Badin, Daniel Tavela Luis e Mario Alfredo de Oliveira

ECUADOR's 2017 TERMINATION OF TREATIES: HOW NOT TO EXIT THE INTERNATIONAL INVESTMENT REGIME 179

Jose Gustavo Prieto Muñoz

ONE BELT, ONE ROAD: NOVAS INTERFACES ENTRE O COMÉRCIO E OS INVESTIMENTOS INTERNACIONAIS 193

Flávio Marcelo Rodrigues Bruno e Marilda Rosado de Sá Ribeiro

III. Artigos Sobre outros TEMAS..................................................... 214

TolerânCIA E REFugIO: UM ENSAIO A PARTIR Do ACORdo EU-TurQUiA 216 Flávia Cristina Piovesan e Ana Carolina Lopes Olsen 
O TRATAMENTO do APÁtridA NA NOVA LEI DE MIGRAÇÃo: ENTRE AVANÇOS E RETROCESSOS...237 Jahyr-Philippe Bichara

O caráter humanista da Lei de Migrações: aVAnços da Lei N. 13.445/2017 E Os desafios DA REGULAMENTAÇÃO. 254 Marcelo Dias Varella, Clarice G. Oliveira, Mariana S.C. Oliveira e Adriana P. Ligiero

Reform of the United Nations Security Council: The Emperor Has No Clothes.268 Ljubo Runjic

A IDEIA DE QUe os LATINO-AMERICANOS PREFEREM O AUTORITARISMO À DEMOCRACIA À luz da reinterpretação dos Critérios do Programa das Nações Unidas para o DesenVolvimento 286

Gina Marcilio Pompeu e Ana Araújo Ximenes Teixeira

A PRoteção da ORIENTAÇÃo SEXUAL E IDENTIDAdE DE GÊNERO DIVERSAS NA CORTE PENAL internacional: Entre Realpolitiks E Os Direitos Humanos

Gustavo Bussmann Ferreira

A desnacionalização e as violações de direitos humanos na República Dominicana. 331 Daniela Menengoti Gonçalves Ribeiro e Rodrigo Ichikawa Claro Silva

CompetênCia do TPI no Caso do ATAque ao hospital de Kunduz: uma análise ENVOLVENDO A JURISDiÇÃo do TPI EM RELAÇÃO A NACIONAIS DE EsTAdOS NÃO-PARTE do Estatuto DE Roma

Filipe Augusto Silva e Renata Mantovani de Lima

A CRIMINALIZAÇÃo DOS IMIGRANTES EM SITUAÇÃo IRREGULAR NA ITÁliA: BIOPOLÍtica E DIREITO PENAL DO AUTOR.

Maiquel Angelo Dezordi Wermuth e Jeannine Tonetto de Aguiar

The New Rules On Trade And Environment Linkage In Preferential Trade Agreements

Alberto do Amaral Júnior e Alebe Linhares Mesquita

Beyond THE Border between the North and the South: towards a Decolonization of EPISTEMOLOGIES AND FIELDS OF RESEARCH ON MERCOSUR 
A aplicabilidade da Convenção de Montreal no direito brasileiro.

Aziz Tuffi Saliba e Alexandre Rodrigues de Souza

REgIME DE TRANSPARÊNCIA FISCAL NA TRIBUTAÇÃo DOS LUCROS AUFERIDOS NO EXTERIOR (CFC RULES): LACUNAS E CONFLITOS NO DIREITO BRASILEIRO

Paulo Rosenblatt e Rodrigo Torres Pimenta Cabral

As Regras Brasileiras de Tributação de Controladas e Coligadas no Exterior: verdadeiras Controlled Foreign Company (CFC) Rules? .......................................465

Melina de Souza Rocha Lukic e Amanda Almeida Muniz

O RETORNO DE BENS CULTURAIS

Aziz Saliba e Alice Lopes Fabris

Direitos culturais e Nações Unidas: uma análise a partir da Declaração Sobre a eliminação de Todas as Formas de Intolerância e Discriminação Baseadas na Religião OU NA CRENÇA

Leilane Serratine Grubba e Márcio Ricardo Staffen

OS REFLEXOS DA PROTEÇÃO INTERNACIONAL DA PROPRIEDADE INTELECTUAL PARA O DESENVOLVIMENTO INTERNO: UMA ANÁLISE SOBRE O SISTEMA PATENTÁRIO BRASILEIRO E A TRANSFERÊNCIA DE TECNOLOGIA

Michele M. Segala e Isabel Christine S. De Gregori

O CASO HIPOTÉTICO DA MORTE DO EMBAIXADOR FRANCÊS NA ESPANHA: DUAS ESPÉCIES DE IUS gentium em Francisco de Vitoria

Rafael Zelesco Barretto

De volta À BeVilaqua: anÁlise ECONÔMICA dA APLICAÇão do ART. $9^{\circ}$ DA LINDB Às OBRIGAÇÕES CIVIS CONTRATUAIS

Danielle Cristina Lanius e Ivo Teixeira Gico Jr 


\title{
Competência do TPI no caso do ataque ao hospital de Kunduz: uma análise envolvendo a jurisdição do TPI em relação a nacionais de Estados não-Parte do Estatuto de Roma*
}

\author{
ICC's competence in the case of the attack \\ of the Kunduz Hospital: an analysis involving \\ the ICC's jurisdiction regarding the nationals of \\ non-Party States of the Rome Statute
}

Filipe Augusto Silva**

Renata Mantovani de Lima***

\section{Resumo}

Pretende-se no presente artigo discorrer sobre a competência ratione materiae, ratione loci, ratione personae e ratione temporis estabelecidas no Estatuto de Roma. Após, analisar-se-á o ataque ao Centro de Trauma de Kunduz, localizado no Afeganistão, por militares Americanos, dentro do contexto de um conflito armado. Subsequentemente, proceder-se-á ao exame da investigação realizada pelos Estados Unidos sobre o incidente. Por fim, verificar-se-á a possibilidade do exercício da jurisdição do TPI sobre o caso. A vertente metodológica adotada: jurídico-teórica; tipo de raciocínio: dedutivo; tipos metodológicos da pesquisa: histórico-jurídico, jurídico-comparativo e jurídico-interpretativo.

Palavras chave: Estatuto de Roma; Tribunal Penal Internacional; Centro de Trauma de Kunduz; Conflito Armado; Crime de Guerra.

* Recebido em 19/09/2017

Aprovado em 29/09/2017

** Bacharel em Direito pela Universidade de Itaúna. Pós-graduado em Direito Penal e Processual Penal pelo Centro Universitário Newton Paiva. Mestre em Direito pelo Programa de pós-graduação Stricto Sensu da Universidade de Itaúna. Advogado. E-mail: remantova@hotmail.com

*** Advogada, Doutora e Mestre pela Pontifícia Universidade Católica de Minas Gerais, tendo realizado suas pesquisas na Universidade de Pisa-Itália, Professora da Graduação e Mestrado da Universidade de Itaúna/MG. Ex Diretora Nacional dos Cursos de Direito do Grupo Ânima Educação. Ex Reitora da Universidade Santa Úrsula no Rio de Janeiro. E-mail: remantova@hotmail.com

\section{Abstract}

It is intended in this paper to broach about the ratione materiae, ratione loci, ratione personae and ratione temporis competence, established in the Rome Statute. After, the attack of the Kunduz Trauma Centre, located in Afghanistan, by American military, within the context of an armed conflict, will be analyzed. Subsequently, an exam of the United States investigation about the incident will be performed. Lastly, the possibility of the exercise of ICC's jurisdiction on the case will be verified. The methodological aspects adopted: juridical-theoretic; reasoning type: deductive; Research methodological types: historical-juristic; juridical-comparative, juridical-interpretative.

Keywords: Rome Statute; International Criminal Court; Kunduz Trauma Centre; Armed Conflict; War Crime. 


\section{INTRODUÇÃO}

No dia 03/10/2015, o Centro de Trauma operado pela Organização Internacional dos Médicos Sem Fronteiras, localizado na cidade de Kunduz, no Afeganistão, foi bombardeado por cerca de uma hora por um avião pertencente aos Estados Unidos. Referido hospital foi completamente destruído e várias pessoas foram mortas ou ficaram feridas como resultado deste ataque. Uma vez que a conduta dos militares Americanos encontra-se tipificada como crime de guerra no Estatuto de Roma, além de ter sido praticada no âmbito de um conflito armado, acredita-se que o Tribunal Penal Internacional (TPI), possua a prerrogativa de exercer sua jurisdição em relação a referidos indivíduos, mesmo que eles não sejam nacionais de um Estado-Parte de seu Estatuto.

O TPI, criado pelo Estatuto de Roma com o intuito de combater a impunidade dos indivíduos perpetradores dos crimes de maior gravidade, que afetam a comunidade internacional como um todo, conta com um importante mecanismo jurisdicional para cumprir com eficiência este objetivo. Referido mecanismo, disposto no artigo 12, 2, "a" de dito Estatuto (ONU, 1998), permite que o Tribunal exerça sua jurisdição em relação a nacionais de Estados não-Parte do Estatuto de Roma, na hipótese do crime ser cometido no território de um Estado-Parte.

Neste sentido, Markus Wagner discorre sobre referida competência em razão do lugar ou do território (ratione loci ou ratione tertiis), estabelecida pelo Estatuto de Roma, sendo que sua explanação servirá como marco teórico para o presente artigo. In verbis:

Uma leitura literal da norma revela que o TPI possui jurisdição sobre aqueles crimes contidos no artigo 5 (1) do Estatuto do TPI, i.e. genocídio, crimes contra a humanidade e crimes de guerra, caso a conduta em questão seja cometida no território de um Estado parte, ou a bordo de uma embarcação ou aeronave, se estas ostentarem a bandeira de ou estiverem registradas em um Estado parte.

Assim sendo, o alcance geográfico do Estatuto do TPI é consideravelmente maior do que qualquer um de seus predecessores, provavelmente melhor simbolizado pelo muito limitado foco geográfico do TPII [Tribunal Penal Internacional para a exIugoslávia] e TPIR [Tribunal Penal Internacional para Ruanda], ambos os quais estavam confinados aos eventos ocorridos na ex-Iugoslávia, no caso do TPII, e em Ruanda e seus países vizinhos, no caso do TPIR. O fundamento para o alcance quase global do TPI já vem estabelecido no Preâmbulo, o qual afirma que "os crimes de maior gravidade, que afetam a comunidade internacional no seu conjunto, não devem ficar impunes". Entretanto, este potencial alcance verdadeiramente global está limitado pela aplicação territorial do Estatuto do TPI àqueles estados que são Estados-parte, um resultado que claramente constitui uma expressão do princípio da soberania estatal. ${ }^{1}$ (WAGNER, 2003, p.483/484).

Tendo em vista que o Afeganistão constitui-se num Estado-parte do Estatuto de Roma desde 2003, surgiu, diante de referido incidente, a possibilidade do TPI exercer sua jurisdição no tocante à nacionais de um país não-Parte do Estatuto de Roma, possibilidade esta que, como se pretende demonstrar ao longo do presente trabalho, deve ser exercida pelo Tribunal em nome do seu objetivo preambular de erradicação da impunidade.

Portanto, o objetivo do presente artigo é examinar as competências ratione materiae, ratione loci, ratione personae e ratione temporis do TPI, construindo uma estrutura doutrinária e jurisprudencial para, logo após, analisar-se o ataque ao Hospital de Kunduz por militares Americanos, determinando-se a viabilidade de exercício da jurisdição do TPI em relação a este incidente.

Neste trabalho, adotar-se-á a vertente metodológica jurídico-teórica, uma vez que se destacará aspectos doutrinários e jurisprudenciais do TPI. O tipo de raciocínio utilizado será o dedutivo, pois partir-se-á do estudo das normas em abstrato do Estatuto de Roma para, após, examinar a sua aplicação ao caso concreto do incidente em Kunduz. Por fim, em relação aos tipos metodológicos da pesquisa, serão empregados o histórico-jurídico, jurídico-comparativo e jurídico-interpretativo (DIAS; GUSTIN, 2013, p.22-29).

\section{Competência do Tribunal Penal INTERNACIONAL}

A competência do TPI define os limites dentro dos quais referido tribunal irá exercer seu poder jurisdicional. A mesma pode ser fixada através da análise de quatro critérios: material (ratione materiae), territorial (ratione loci), pessoal (ratione personae) e temporal (ratione temporis).

1 Tradução nossa. 


\subsection{Competência em razão da matéria (ratione materiae)}

A competência em razão da matéria diz respeito aos crimes passíveis de serem julgados pelo TPI. Estão elencados no artigo $5^{\circ}$ do Estatuto de Roma (ONU, 1998), a saber, o crime de genocídio, os crimes contra a humanidade, os crimes de guerra e o crime de agressão. Esclarecem Brina e Lima (2006, p.106) que "Esses delitos, classificados como core crimes e igualmente denominados como coletivos ou em massa, afetam a toda humanidade, sendo irrelevante o apontamento do direito individual violado".

No que tange aos crimes contra a humanidade, uma questão importante surgiu durante as negociações do Estatuto de Roma: se era necessária a existência de nexo causal com algum conflito armado para que ocorresse a sua caracterização, ou se seriam também passíveis de punição na ausência de tais conflitos. As nações favoráveis ao nexo com conflitos armados apresentaram como argumentos os precedentes do Estatuto de Nuremberg e da ex-Iugoslávia. Ocorre que, caso fosse necessária esta vinculação com conflitos armados para que os crimes contra a humanidade fossem punidos pelo Estatuto de Roma, criar-se-ia uma relação de duplicidade com a figura dos crimes de guerra (WAGNER, 2003, p.434). Nesse sentido:

Uma minoria de delegações participantes da Conferência de Roma acreditavam fortemente que os crimes contra a humanidade poderiam ser cometidos somente no contexto de um conflito armado. Entretanto, a maioria das delegações acreditavam que tal limitação teria tornado os crimes contra a humanidade largamente redundante, uma vez que iriam subsumir-se, na maioria dos casos, à definição de "crimes de guerra". Na visão da maioria, referida restrição teria sido inconsistente com os progressos pósNuremberg, conforme observado em declarações da Comissão de Direito Internacional (CDI), do TPII e de outros comentadores, e refletidos em instrumentos dirigidos a crimes específicos contra a humanidade, como a Convenção sobre o Genocídio e a Convenção sobre o Apartheid.

Uma das características mais importantes da definição no estatuto do TPI é que a mesma não faz nenhuma referência a um nexo com conflitos armados, afirmando que os crimes contra a humanidade podem ocorrer não apenas durante um conflito armado, mas também durante tempos de paz ou de conflitos civis. Esse resultado foi essencial para a efetividade prática do TPI em responder a atrocidades de larga-escala cometidas por governos contra sua própria população. ${ }^{2}$ (ROBINSON, 1999 , p.45/46).

Já em relação aos argumentos sobre os precedentes contidos no Estatuto do Tribunal Penal Internacional de Nuremberg e no Estatuto do Tribunal Penal Internacional da ex-Iugoslávia, exigindo a vinculação dos crimes contra a humanidade a conflitos armados, existe uma explicação para que referida regra não se aplique ao Estatuto de Roma.

Pois bem, em 1945, os atos criminosos perpetrados pelos nazistas contra civis em territórios fora da Alemanha apresentaram menos dificuldade legal em relação ao seu processo de julgamento, uma vez que o direito internacional já proibia a perseguição de civis dentro de territórios ocupados. Ocorre que, muitos dos advogados Aliados, durante a preparação para o processo do pós-guerra, não acharam legalmente razoável processar os nazistas por crimes cometidos contra alemães dentro da Alemanha, o que foi prontamente criticado pela população, principalmente por organizações não-governamentais judias, fazendo com que houvesse uma mudança neste entendimento e, consequentemente, ficou acordado que tais crimes iriam ser julgados sob a rubrica de "crimes contra a humanidade" (SCHABAS, 2004, p.42).

Entretanto, os Aliados, preocupados com o modo que este entendimento poderia repercutir em relação ao tratamento que dispensavam às minorias dentro de seus territórios e colônias, decidiram por insistir que os crimes contra a humanidade só poderiam ser cometidos se estivessem associados aos outros crimes passíveis de persecução legal dentro da esfera jurisdicional do Tribunal de Nuremberg, a saber, os crimes de guerra e os crimes contra a paz. Desta forma, criou-se um requisito vinculativo entre os crimes contra a humanidade e conflitos armados (SCHABAS, 2004, p.42). Porém:

Insatisfação com tal limitação surgiu dentro
de semanas do julgamento de Nuremberg. A
Assembleia Geral das Nações Unidas decidiu
definir a forma mais flagrante de crime contra a
humanidade, qual seja, o genocídio, como uma
ofensa distinta que poderia ser cometida em tempo
de paz, bem como em tempo de guerra. Ao longo
dos anos, desde 1945, houveram várias variantes na
definição de crimes contra a humanidade, alguma
delas eliminando o nexo com conflito armado. Isso
instigou muitos a sugerir que, do ponto de vista do
direito consuetudinário, a definição tinha evoluído

2 Tradução nossa. 
para cobrir atrocidades cometidas em tempo de paz. Mas o próprio Conselho de Segurança turvou as águas em 1993, quando estabeleceu o Tribunal Penal Internacional para a ex-Iugoslávia. $\mathrm{O}$ artigo 5 do Estatuto deste tribunal estabelece que os crimes contra a humanidade devem ser cometidos "em conflitos armados, sejam eles de carácter internacional ou interno". Um ano mais tarde, entretanto, o Conselho de Segurança não insistiu no nexo quando estabeleceu o Tribunal Penal Internacional para Ruanda. Em 1995, em sua célebre decisão jurisdicional do caso Tadic, a Câmara de Apelações do Tribunal Penal Internacional para a ex-Iugoslávia descreveu o nexo como "obsolescente", e disse que "não há base lógica ou legal para este requisito, sendo abandonado na prática Estatal subsequente em relação a crimes contra a humanidade. Desde então, a Câmara de Apelações têm descrito o nexo com conflito armado, estabelecido no Artigo 5 do Estatuto do Tribunal Iugoslavo como sendo "puramente jurisdicional". (SCHABAS, 2004, p.42).

Este entendimento foi reafirmado no caso Dragan Nikolic (Caso no IT-94-2), no qual a Câmara de Julgamento do Tribunal Penal Internacional para a ex-Iugoslávia (TPII) decidiu que, apesar do artigo 5 do Estatuto do TPII exigir um nexo com conflitos armados, tal requisito seria desnecessário no âmbito do direito internacional para a configuração de crime contra a humanidade (HWANG, 1998, p.480).

Avançando, no que diz respeito ao crime de guerra, o artigo $8^{\circ}$ do Estatuto de Roma (ONU, 1998) define, de forma pormenorizada, as condutas que o caracterizam. Estes ilícitos criminais pressupõe a existência de um conflito armado associados às condutas praticadas, o que pode ser apreendido pela simples leitura de referido artigo, que vincula expressamente os atos descritos em seu texto à conflitos armados.

Além disso, o documento intitulado "Elementos dos Crimes” (TPI, 2011) - adotado pela Assembleia dos Estados Partes do Estatuto de Roma, e que, conforme preconiza o artigo $9^{\circ}$ deste mesmo Estatuto (ONU, 1998), tem como escopo auxiliar o Tribunal a interpretar e aplicar seus artigos $6^{\circ}, 7^{\circ}$ e $8^{\circ}$ - também ressalta que todas as condutas descritas no artigo $8^{\circ}$ devem ocorrer dentro do contexto ou estar associadas a um conflito armado, seja ele de caráter internacional ou não.

Neste contexto sobre o vínculo com conflitos armados cabem duas observações: primeiramente, alguns crimes de guerra, particularmente aqueles relativos à

3 Tradução nossa. repatriação de prisioneiros de guerra, podem ser cometidos após a conclusão das hostilidades, quando não há mais conflito armado. A segunda observação refere-se ao fato de que para uma conduta descrita no artigo $8^{\circ}$ do Estatuto de Roma ser punível perante o TPI, é necessário que, além de ser cometida dentro de um contexto de guerra estabelecida, exista um nexo entre o ato perpetrado e o conflito armado. Este último requisito foi desenvolvido pela jurisprudência dos tribunais ad hoc ${ }^{4}$ (SCHABAS, 2004, p.56/57).

Em relação aos incisos que constituem o artigo $8^{\circ}$, o seu inciso 1 (ONU, 1998) estabelece uma "cláusula limitadora" da jurisdição do TPI. Referida cláusula foi proposta pelos Estados Unidos em 1997 (ONU, 1997), na ocasião da $54^{a}$ e $55^{a}$ reuniões do Comitê Preparatório sobre a criação de um Tribunal Penal Internacional, sendo que:

Durante as negociações, a necessidade de uma cláusula limitadora foi uma questão muito controversa. Em apoio à limitação, argumentouse que apenas ocorrências sistemáticas ou em larga-escala de crimes de guerra seriam motivo de preocupação para a comunidade internacional e, portanto, justificar a análise pelo Tribunal. Também se argumentou que uma cláusula limitadora ajudaria o Tribunal a evitar ficar sobrecarregado por casos pequenos ou isolados. De uma importância adicional, particularmente para os Estados Unidos, proporcionaria uma salvaguarda contra o exercício de jurisdição sobre casos isolados de crimes de guerra, que poderia, por exemplo, ser cometido por um soldado Americano servindo no exterior, por exemplo, numa operação ordenada pelas Nações Unidas.

Aqueles contrários a uma cláusula limitadora sustentaram que isto introduziria uma falsa distinção entre diferentes categorias de crimes de guerra. Argumentou-se que uma salvaguarda contra o exercício de jurisdição sobre casos isolados já constava no Estatuto através do princípio da complementaridade: se incidentes isolados de crimes de guerra fossem devidamente processados por um tribunal nacional, o Tribunal não lidaria com tais crimes. Uma limitação poderia, portanto, na prática, ter o efeito de desencorajar os tribunais nacionais a processar referidos casos incidentais. ${ }^{5}$ (HEBEL; ROBINSON, 1999, p.107/108).

No final, a redação do inciso em comento acabou por contemplar uma "limitação sem limites" (HEBEL; ROBINSON, 1999, p.124), uma vez que, apesar de res-

4 Ver caso "Procurador v. Kunarac et al. (IT-96-23 \& 23/1)": Julgamento datado de 22/02/2001, parágrafo 568.

5 Tradução nossa. 
tringir a competência do Tribunal a crimes de guerra "cometidos como parte integrante de um plano ou de uma política ou como parte de uma prática em larga escala desse tipo de crimes", tal restrição veio precedida pela expressão "em particular", o que garante ao Tribunal a prerrogativa de analisar cada caso concreto e exercer sua jurisdição quando entender necessário.

O inciso 2 do artigo $8^{\circ}$ (ONU, 1998) define quatro categorias de crimes de guerra: dois pertinentes à conflitos armados internacionais (alíneas "a" e "b") e dois relativos à conflitos armados não internacionais (alíneas "c" e "e"). Esta separação entre conflitos armados de caráter internacional e não-internacional surgiu no âmbito da regulação histórica de guerras e conflitos pelo direito internacional, sendo que, da Paz de Vestefália até a Segunda Guerra Mundial, as leis internacionais de guerra aplicavam-se apenas à conflitos entre Estados. Existia a possibilidade de que as leis de guerra se aplicassem a guerras civis, mas somente nos casos em que o Estado envolvido, ou um terceiro Estado, reconhecesse a "beligerância" da parte insurgente (AKANDE, 2012, p.1/2).

No entanto, o reconhecimento de "beligerância" não era um critério que fornecia uma base certa e concreta em relação ao momento e a quais conflitos o Direito Internacional Humanitário se aplicaria. Com isso em mente, o Comitê Internacional da Cruz Vermelha (CICV) começou a desempenhar seu papel no âmbito de conflitos internos, tanto que, na Guerra Civil Espanhola (1936 a 1939), obteve o acordo de ambas as partes no conflito em respeitar as Convenções de Genebra de 1864 e 1906. Após a Segunda Guerra Mundial, o CICV sustentou que as Convenções de Genebra de 1949 deveriam aplicar-se tanto a conflitos armados internacionais como não-internacionais, proposta esta que sofreu grande oposição de países que temiam uma redução em sua soberania no que tange a sua capacidade de contenção de revoltas dentro de suas fronteiras (WILLMOTT, 2004, p.5). Assim, referida proposta:

[...] foi rejeitada, porém, em favor do artigo $3^{\circ}$ Comum às Convenções de Genebra, o qual claramente estabelece que a aplicação das regras do direito humanitário dependerá da natureza do conflito. $\mathrm{O}$ artigo $3^{\circ}$ Comum foi primariamente desenvolvido com o objetivo de regular conflitos

6 Para uma análise mais aprofundada do tema ver: BARTELS, Rogier. Timelines, borderlines and conflicts. The historical evolution of the legal divide between international and noninternational armed conflicts. não-internacionais. Comparado com o resto das Convenções de Genebra, as quais contém um alto grau de regulamentação de conflito armado, o artigo $3^{\circ}$ Comum é relativamente modesto neste aspecto. Ele contém somente o que parecem ser os elementos "centrais" das Convenções de Genebra, como o tratamento humano daqueles que não estejam participando do combate e a obrigação das partes de cuidarem dos doentes e feridos. É agora incontestável que estas regras contidas no artigo $3^{\circ}$ Comum representam o direito internacional consuetudinário. ${ }^{7}$ (ODERMATT, 2013, p.20).

O principal fator que diferencia um conflito armado internacional de um não-internacional diz respeito às partes envolvidas nas hostilidades. Conflitos armados internacionais, em regra, são travados entre Estados, sendo que, na teoria, também podem ocorrer entre um Estado e um movimento nacional libertário. Porém, é muito difícil que um Estado admita, na prática, que esteja envolvido em uma guerra de libertação nacional, uma vez que isso implicaria na aceitação de que o mesmo é um regime racista, um ocupante estrangeiro ou um dominador colonial (SIVAKUMARAN, 2011, p.237).

Em contrapartida, os conflitos armados internos são travados entre forças armadas governamentais e grupos armados não-estatais (facções rebeldes), ou entre grupos armados inimigos dentro de um Estado, sem que haja qualquer intervenção nas hostilidades por parte de algum Estado estrangeiro ou da ONU (VERHOEVEN, 2007, p.7).

Neste ponto, poder-se-ia questionar qual a importância prática desta distinção entre conflitos armados internacionais e não-internacionais para o Direito $\mathrm{Hu}$ manitário. Atualmente, apesar de existir uma tendência crescente pela diminuição da importância desta distinção, ela ainda é relevante (BARTELS, 2009, p.40/41). Nesse sentido:

O direito internacional humanitário tenta aliviar o sofrimento causado pela guerra e tenta proteger os fracos durante conflitos. Por isso, as quatro Convenções de Genebra de 1949 e seus dois protocolos adicionais de 1977 estabelecem regras com o escopo de salvaguardar os feridos, doentes, náufragos, prisioneiros de guerra e civis o tanto quanto possível dos flagelos da guerra. Consequentemente, num primeiro momento, não parece ser relevante se o conflito é travado por vários Estados ou entre vários grupos armados dentro de um Estado. Entretanto, e infelizmente, isto é relevante. A proteção oferecida pelo direito internacional humanitário em relação a um conflito

7 Tradução nossa. 
armado internacional ou Interestatal é muito mais ampla do que aquela oferecida a um conflito armado não-internacional ou um conflito armado dentro de um Estado, apesar do sofrimento ser o mesmo ou até mesmo mais severo num conflito armado interno. Como resultado, a natureza do conflito realmente faz diferença, e uma delimitação correta pode ser de vital importância para a proteção das pessoas contra a barbárie, que ainda se encontra frequentemente presente em conflitos armados. ${ }^{8}$ (VERHOEVEN, 2007, p.3).

Atualmente, existem conflitos armados que não se encaixam nas definições clássicas de conflitos armados internacionais e não-internacionais. São os chamados "conflitos armados internacionalizados", que apresentam características tanto de um quanto de outro, formando uma espécie de conflito híbrido ou misto (CRAWFORD, 2008, p.20). Dentre várias situações hipotéticas que se encaixam em referido conceito, pode-se citar como exemplo a guerra travada entre forças governamentais de um determinado Estado e facções rebeldes ou grupos armados, com a intervenção ${ }^{9}$ de um ou mais Estados estrangeiros apoiando o governo, as facções rebeldes ou os grupos armados (VERHOEVEN, 2007, p.15). Sobre o tema, a Câmara de Apelações do Tribunal Penal Internacional para a ex-Iugoslávia, em sua decisão datada de 15/07/1999 no caso Dusko Tadic (Caso no IT-94-1), afirmou que:

É indiscutível que um conflito armado é
internacional se o mesmo ocorre entre dois ou mais
Estados. Ademais, no caso de um conflito armado
interno se desencadear no território de um Estado,
ele pode tornar-se internacional (ou, dependendo
das circunstâncias, possuir caráter internacional
ao lado de um conflito armado interno) se (i)
outro Estado intervir naquele conflito através de
suas tropas, ou alternativamente se (ii) alguns dos
participantes no conflito armado interno agir em
nome daquele outro Estado. ${ }^{10}$ (TPII, 1999, p.34,
parágrafo 84).

No âmbito do Estatuto de Roma, há condutas consideradas como crimes de guerra tanto no caso de conflitos armados internacionais como no caso de conflitos armados internos, sendo que a proteção dada pelo Estatuto é mais ampla nos conflitos de índole internacional.

\footnotetext{
8 Tradução nossa.

9 Sobre as formas de intervenção de Estados estrangeiros em conflitos armados não-internacionais ver: SCHINDLER, Dietrich. International humanitarian law and internationalized internal armed conflicts; VITÉ, Sylvain. Typology of armed conflicts in international humanitarian law: legal concepts and actual situations.
}

10 Tradução nossa.
Por exemplo, o ataque intencional a hospitais é considerado como crime de guerra em ambas as espécies de conflito armado (artigo $8^{\circ}, 2$, "b", ix e artigo $8^{\circ}, 2$, "e", iv). Já a proibição em se utilizar armas ou métodos que causem ferimentos supérfluos ou sofrimento desnecessário (artigo 8, 2, "b”, xx) só está presente no contexto de conflitos armados internacionais.

No entanto, é importante notar que, após a entrada em vigor de uma emenda ao artigo $8^{\circ}$ do Estatuto de Roma, em 26/09/2012, acrescentando condutas aos conflitos de índole não-internacional que antes eram exclusivas dos conflitos internacionais, referida diferença de proteção legislativa entre ambos tipos de conflito foi reduzida consideravelmente. Cumpre ressaltar, porém, que esta emenda é válida somente para os países que ratificaram tal emenda ao artigo $8^{\circ}$, estando este número atualmente em 34 (trinta e quatro) países ratificantes ${ }^{11}$.

Esclarecido este ponto, o artigo $8^{\circ}$, 2, "a" do Estatuto de Roma (ONU, 1998) define como crimes de guerra a prática de condutas que se traduzem em graves violações às Convenções de Genebra como, por exemplo, o homicídio doloso (i) e a tomada de reféns (viii). No tocante à alínea "b", são descritas condutas que derivam de várias fontes legais e consuetudinárias aplicáveis à conflitos armados internacionais como: a Convenção de Haia de 1907 (Leis e Costumes de Guerra em terra); o Protocolo I Adicional às Convenções de Genebra (Proteção das Vítimas de Conflitos Armados Internacionais); a Declaração de Haia de 1899 que trata sobre Projéteis Expansivos; o Protocolo de Genebra de 1925 sobre a proibição do uso de Gases Venenosos (DÖRMANN, 2003, p.343/344).

O artigo 8, 2, “c" (ONU, 1998) trata sobre condutas que constituem graves violações ao artigo $3^{\circ}$ comum às Convenções de Genebra como, por exemplo, os atos de violência contra a vida e a pessoa, em particular, o homicídio, a mutilação, o tratamento cruel e a tortura. Por fim, a alínea "e" cobre outras graves violações de leis e costumes aplicáveis à conflitos armados não-internacionais derivadas, por exemplo, da Convenção de Haia de 1907 e do Protocolo II Adicional às Convenções de Genebra que versa sobre a Proteção das Vítimas de Conflitos Armados sem Caráter Internacional (DÖRMANN, 2003, p.344/345).

11 Informação disponível no site: https://treaties.un.org/ pages $/$ ViewDetails.aspx? src $=$ TREATY\&mtdsg_no $=$ XVIII-10a\&chapter=18\&clang=_en. 
Para que o indivíduo se enquadre em qualquer uma das condutas descritas no artigo $8^{\circ}$, não é exigível, de acordo com o documento "Elementos dos Crimes" (TPI, 2011), que o agente proceda a uma avaliação legal sobre a existência ou não de um conflito armado ou sobre sua natureza internacional ou interna. Assim, também não é necessário que o agente esteja ciente dos fatos que determinaram o caráter internacional ou interno do conflito. $\mathrm{O}$ único requisito geral, dentro deste contexto, que necessita estar presente, é a ciência por parte do agente das circunstâncias fáticas que estabeleceram a existência do conflito armado.

\subsection{Competência em razão do lugar (ratione loci)}

A competência territorial, em sua acepção clássica, é estabelecida em razão de um determinado espaço geográfico onde ocorrem os fatos que poderão ser conhecidos, processados e julgados pela autoridade estatal (BRINA; LIMA, 2006, p.141). No que tange ao TPI, o artigo 12, 2, “a”, do Estatuto de Roma (ONU, 1998) estabelece o seu poder jurisdicional de conhecer, processar e julgar crimes de acordo com o local onde foram cometidos. Preliminarmente, é importante esclarecer-se sobre este ponto que:

\begin{abstract}
De acordo com o Direito Internacional, os crimes de genocídio, guerra e os crimes contra a humanidade possuem jurisdição universal. Isso implica atribuir o direito ou mesmo a obrigação a qualquer Estado do globo para julgar crimes dessa natureza, mesmo na ausência de nexo quanto à nacionalidade do perpetrador, da vítima ou do lugar em que o delito fora cometido. Por essa razão, algumas delegações pugnaram pela transposição desse sistema também para o âmbito do Tribunal. Contudo, mais uma vez, considerações políticas, devido às repercussões nas relações diplomáticas, impediram uma maior autonomia jurisdicional do Tribunal, restringindo, consequentemente, sua esfera de aplicação territorial. Desse modo, o campo de incidência territorial, no caso específico do TPI, ficou restrito aos Estados signatários do Tratado de Roma nos quais tenham sido cometidos atos delituosos; ou, se a bordo de um navio ou aeronave, o Estado de sua respectiva matrícula. (BRINA; LIMA, 2006, p.141-143).
\end{abstract}

Apesar de não possuir jurisdição universal, o artigo 12 do Estatuto de Roma (ONU, 1998), conforme visto, prevê a possibilidade de que nacionais de países não-Parte do Estatuto sejam julgados pelo TPI, desde que o crime tenha sido cometido no território de um Estado-parte. Esta norma legal sofreu forte oposição de alguns países, principalmente dos Estados Unidos, chegando os mesmos a questionarem a própria legalidade do TPI, uma vez que referida norma supostamente feriria a regra pacta tertiis nec nocent nec prosunt, consagrada no artigo 34 da Convenção de Viena sobre o Direito dos Tratados, que prega que um tratado não cria obrigações nem direitos para um terceiro Estado sem que haja o seu consentimento (WAGNER, 2003, p.487).

No entanto, este argumento é falho por embasar-se numa confusão entre as noções de obrigação e interesse. O Estatuto de Roma não cria nenhuma obrigação aos Estados não-parte do mesmo, uma vez que seu artigo 17 consagra o princípio da Complementaridade, ou seja, o TPI somente exercerá sua jurisdição caso o Estado competente para processar o crime não queira ou não possua condições de fazê-lo. Isso se revela como uma questão envolvendo mero interesse dos Estados não-parte, e não como uma obrigação criada sem o seu consentimento, o que demonstra que o Estatuto de Roma claramente não viola as regras do Direito Internacional (MÉGRET, 2001, p.249). Também nesse sentido:

[...] a alegação que lá [no Estatuto de Roma] existe uma obrigação para Estados não-partes carece de uma fundamentação clara. O Estatuto do TPI não impõe uma obrigação a um Estado não-parte em cooperar com o Tribunal, de acordo com seus artigos 86 et seq. Essa não-obrigação refere-se a qualquer tipo de assistência concebível, e.g. a entrega de supostos perpetradores ou evidência. Parece que dois conceitos distintos estão entrelaçados nesta linha de argumento. Isto diz respeito à imposição de obrigações por tratados a Estados não-partes, por um lado, e o exercício de jurisdição sobre nacionais de tais estados. Ademais, tanto a nacionalidade (ativa) quanto a territorialidade são princípios bem reconhecidos como bases para a jurisdição. Neste sentido, o regime jurisdicional do TPI não é extraordinário. É, além do mais, reconhecido que o estado cujo o território a conduta criminal ocorreu, possui jurisdição concorrente com o estado de nacionalidade. Caso se aceite esta proposição - e a maioria dos países com um sistema legal Anglo-Americano concordam plenamente com a territorialidade como a principal base para o exercício da jurisdição - é direito territorial do estado em processar a pessoa dentro de seu próprio sistema legal, extraditar aquela pessoa para outro país com um título jurisdicional, ou entregála a outro foro, que poderia ser o TPI. Referida base jurisdicional está incorporada na maioria das convenções de direito criminal internacional, nas quais tal distinção entre nacionais e não-nacionais não existe. Assim, não se pode alegar que o Estatuto do TPI cria qualquer obrigação para um Estado não-parte. Pelo contrário, o regime jurisdicional do TPI segue de perto o de muitos sistemas legais 


$$
\text { domésticos. }^{12} \text { (WAGNER, 2003, p.487-489). }
$$

A regra da territorialidade estabelecida pelo artigo 12 do Estatuto de Roma (ONU, 1998) pode gerar dúvidas em relação à sua aplicação em certos casos que envolvam o território de Estados-parte e não-parte como, por exemplo, quando uma conduta criminosa é perpetrada no território de vários países ou quando um crime é praticado em um Estado, mas produza seu resultado no território de outro. Atualmente, é possível afirmar que, nestes casos, todos os Estados que possuírem uma conexão com a conduta poderão exercer plenamente sua jurisdição e, por conseguinte, também o TPI, respeitado o princípio da Complementaridade (WAGNER, 2003, p.484/485).

Quando o artigo 12 afirma que o TPI será competente nos casos onde a conduta tenha ocorrido dentro dos limites territoriais de um Estado-parte, sendo silente quanto ao resultado que a mesma possa ocasionar, não é prudente que tal regra seja interpretada de forma literal, sob pena de gerar situações absurdas. Por exemplo, caso um ataque perpetuado por um agente localizado no território de um Estado não-parte venha a atingir o espaço geográfico de um Estado-parte, obviamente que este último, em cujo território ocorreu o resultado, será competente para processar o crime, assim como o TPI. Pensar o contrário resultaria na legitimação de situações incoerentes com o escopo do Estatuto de Roma, bem como do próprio Direito Internacional, nas quais criminosos se furtariam à jurisdição do Tribunal.

\subsection{Competência em razão da pessoa (ratione personae)}

A competência em razão da pessoa, sob o Estatuto de Roma, é definida levando-se em conta certos atributos ostentados pelo agente que cometeu o crime. Em seu artigo 12, 2, "b", o Estatuto (ONU, 1998) preconiza que o TPI poderá exercer sua jurisdição caso o perpetrador da conduta criminosa possua a nacionalidade de um Estado-parte do Estatuto, adotando-se, desta forma, o Princípio da Nacionalidade ou Personalidade Ativa. Portanto, a nacionalidade da vítima não influi para estabelecer a competência ratione personae do Tribunal. Porém, é importante destacar que:

Uma exceção a esta estreita autorização existe, entretanto. O TPI possui, virtualmente, - ao menos numa base legal e deixando considerações políticas de lado - jurisdição pessoal ilimitada para aquelas situações que lhe são indicadas pelo Conselho de Segurança, sob o artigo 13 (b) de seu Estatuto. Apenas através de tal indicação o requisito da nacionalidade não existe. $O$ mesmo também é verdade para o requisito de que a suposta conduta deva ter sido realizada no território de um Estado parte. $^{13}$ (WAGNER, 2003, p.483).

Ainda sobre a competência ratione personae, "[...] a regra é que o Tribunal só exerce sua jurisdição para pessoas físicas maiores de 18 anos. Portanto, excluem-se da competência do TPI, v.g., os Estados, as organizações internacionais e as pessoas jurídicas de direito privado" (MAZZUOLI, 2015, p.1051). Esta regra encontra-se consagrada nos artigos 25 e 26 do Estatuto de Roma (ONU, 1998).

Por fim, o artigo 27 do Estatuto de Roma (ONU, 1998) afirma que nenhuma qualidade oficial do indivíduo o eximirá de sua responsabilidade criminal perante o TPI, nem constituirá motivo, por si só, para a redução de sua pena em caso de condenação. Além disso, referido artigo esclarece que "As imunidades ou normas de procedimento especiais decorrentes da qualidade oficial de uma pessoa, nos termos do direito interno ou do direito internacional, não deverão obstar a que o Tribunal exerça a sua jurisdição sobre essa pessoa".

Entretanto, existe uma exceção específica a esta regra, envolvendo à cooperação dos Estados-parte na entrega de indivíduos ao TPI. O artigo 98, 1, do Estatuto de Roma (ONU, 1998) prega que o Tribunal não poderá dar andamento a um pedido de entrega ou de auxílio, caso isto leve o Estado-parte requerido a agir de forma incompatível com as obrigações por ele assumidas perante o Direito Internacional, em matéria relacionada às imunidades de um terceiro Estado, a menos que este último concorde com o levantamento de tais imunidades. Isto não significa que o Estado-parte esteja proibido de efetuar a entrega voluntariamente, sendo que, caso esta seja realizada, o agente entregue sob a jurisdição do TPI não terá qualquer espécie de tratamento especial em relação a outros réus (SCHABAS, 2004, p.81). De forma semelhante:

[...] o Tribunal também está proibido de realizar um pedido de entrega que exigisse de um Estado parte a agir inconsistentemente com certos acordos internacionais concluídos com um terceiro Estado. A disposição - Artigo 98 (2) - foi feita com o

12 Tradução nossa.

13 Tradução nossa. 
objetivo de assegurar que uma classe bastante comum de tratados conhecidos como "acordos de status de força" (ou SOFAs) [em inglês: status of forces agreements] não fossem enfraquecidos ou neutralizados pelo Estatuto. Os SOFAs são utilizados para garantir que as forças de manutenção da paz ou tropas localizadas num país estrangeiro não estejam sujeitas à jurisdição dos tribunais deste país. Alguns advogados engenhosos do Departamento de Estado dos Estados Unidos tentaram perverter o Artigo 98 (2), redigindo tratados que escudassem todos os nacionais Americanos do Tribunal. Vários Estados parte sucumbiram à pressão de Washington e concordaram com tais acordos. ${ }^{14}$ (SCHABAS, 2004, p.81).

Desta forma, logo após a entrada em vigor do Estatuto de Roma, os Estados Unidos partiram numa empreitada internacional para convencer os demais Estados a assinarem referidos acordos bilaterais de não-entrega de seus nacionais, tanto que, em 2011, noventa e cinco acordos desta natureza se encontravam vigentes $^{15}$, muitos deles envolvendo países parte do Estatuto. O tamanho e a força de tal empreitada foram tão intensos que acabaram se tornando um dos itens na pauta de discussão da $2450^{a}$ Sessão do Conselho Europeu (CE, 2002), datada de 30/08/2002, na qual foram estabelecidos Princípios Guias com o escopo de preservar a integridade do Estatuto de Roma no tocante às obrigações de cooperação assumidas perante o TPI. Ademais, uma opinião conjunta (CRAWFORD; SANDS; WILDE, 2003) sobre o tema também foi requerida pelos advogados do Comitê de Direitos Humanos e Fundação Médica para as vítimas de Tortura, com o objetivo de esclarecer a compatibilidade do artigo 98, 2, do Estatuto de Roma com referidos acordos bilaterais dos Estados Unidos.

O intento dos Estados Unidos em proteger seus nacionais da jurisdição do TPI com a negociação de referidos acordos é evidente. No entanto, indaga-se se tal conduta de aceitação destes acordos por Estados-parte do Estatuto de Roma feriria as regras impostas pelo Direito Internacional, mais especificamente aquelas estabelecidas pela Convenção de Viena sobre os Direitos dos Tratados (CVDT). Nesse sentido, o artigo 18 de dita Convenção (ONU, 1969) determina que os Estados não podem frustrar o objeto e a finalidade de um tratado ao qual tiverem assinado ou trocado instrumentos constitutivos, bem como que tiverem expressado seu

14 Tradução nossa.

15 Informação disponível em http://www.amicc.org/usicc/bial- consentimento em obrigar-se no período que preceda a sua entrada em vigor.

Ora, é amplamente aceito que a finalidade do Estatuto de Roma é erradicar a impunidade que protege aqueles que cometem os crimes de maior gravidade, os quais afetam a comunidade internacional como um todo. Esta conclusão pode ser embasada na redação dos parágrafos quinto e sexto do próprio preâmbulo do Estatuto. Assim, caso se submetam a esses acordos bilaterais de não-entrega de indivíduos, os Estados-parte do Estatuto de Roma estarão em manifesta violação de suas obrigações perante o Direito Internacional, uma vez que referidos acordos têm como escopo impedir a entrega ou a transferência de pessoas à jurisdição do TPI, criando uma espécie de imunidade exclusiva a estes indivíduos, o que tem o condão de fomentar a impunidade (TAN JUNIOR, 2003, p.1130/1131).

Nesse contexto, também é importante notar que referidos acordos bilaterais não possuem qualquer mecanismo que garanta que as pessoas proibidas de serem entregues ou transferidas ao TPI, sejam sujeitas a investigação por uma outra autoridade competente pelos crimes cometidos. Percebe-se, portanto, que o único objetivo desses acordos é privar o TPI de exercer sua jurisdição sob certas pessoas. No máximo, tais acordos constam em sua redação ${ }^{16}$ que os países contratantes expressam suas intenções de, quando adequado, investigar e processar os crimes sob a jurisdição do TPI, o que, nem remotamente, é suficiente para afastar a potencial impunidade dos indivíduos que os acordos bilaterais de não-entrega visam proteger (TAN JUNIOR, 2003, p.1131/1132).

Ademais, um acordo que proiba um Estado-parte de entregar um suspeito ao TPI, infringe o dever geral de cooperação plena consagrado no artigo 86 do Estatuto de Roma (ONU, 1998), o que, por sua vez, também viola o artigo 26 da CVDT (ONU, 1969), que prega que todo tratado em vigor obriga as partes e deve ser cumprido por elas de boa-fé (BENZING, 2004, p.218).

Outra questão pertinente à validade dos acordos bilaterais de não-entrega perante o artigo 98, 2, do Estatuto de Roma (ONU, 1998) diz respeito ao momento

16 Um modelo padrão dos Acordos Bilaterais de Não-Entrega pode ser encontrado em: BENZING, Markus. U.S. Bilateral NonSurrender Agreements and Article 98 of the Statute of the International Criminal Court: An Exercise in the Law of Treaties, p.191/192. 
da conclusão dos mesmos, ou seja, se são anteriores ou posteriores à entrada em vigor, ou até mesmo à assinatura, de referido Estatuto. O artigo 31 da CVDT (ONU, 1969) preconiza que os tratados devem ser interpretados de boa-fé, de acordo com o sentido comum atribuível contextualmente aos seus termos e à luz de seu objetivo e finalidade. Pois bem, o propósito do artigo 98, 2, do Estatuto de Roma é proteger o Estado-parte de uma situação que envolva obrigações internacionais conflitantes, ou seja, prevenir que o mesmo, uma vez que já possuísse previamente um acordo de não-entrega firmado com um Estado não-parte, tivesse de escolher entre o envio ou não de um indivíduo ao TPI, violando, desta forma, sua obrigação com uma das partes interessadas. Tendo em vista este contexto, um Estado-parte não pode se aproveitar, de boa-fé, da proteção proporcionada pelo artigo 98, 2, caso tenha se colocado, voluntariamente, numa situação de conflito obrigacional, após tornar-se parte do Estatuto de Roma (BENZING, 2004, p.216-218). Por fim:

\begin{abstract}
[...] a história da negociação confirma as conclusões encontradas. Na Conferência de Roma, os negociadores estavam preocupados com o fato de que os estados talvez estariam relutantes em ratificar o Estatuto, devido a preocupações em se violar acordos concluídos previamente, em particular os SOFAs e tratados bilaterais de extradição. O artigo 98 (2) foi especificamente introduzido para lidar com essa preocupação. ${ }^{17}$ (BENZING, 2004, p.219).
\end{abstract}

\subsection{Competência em razão do tempo (ratione temporis)}

O artigo 11 do Estatuto de Roma (ONU, 1998) afirma que o TPI somente terá competência em relação aos crimes cometidos após a sua entrada em vigor (01/07/2002), sendo que, caso algum país venha a se tornar parte depois desta data, o Tribunal só será competente para processar os atos criminosos praticados posteriormente à vigência do Estatuto para referido país. No entanto, o Estado poderá fazer uma declaração, nos termos do artigo 12, 3, do Estatuto de Roma, para aceitar a jurisdição do TPI em relação a crimes cometidos no lapso temporal que compreende a entrada em vigor internacional do Estatuto, e a entrada em vigor do Estatuto para tal Estado.

Logo, nenhum crime cometido antes da entrada em vigor internacional do Estatuto de Roma, na data de 01/07/2002, poderá ser julgado pelo TPI, ainda que se trate da situação excepcional, autorizada pelo artigo 13, "b", do Estatuto, que permite ao Conselho de Segurança da ONU, agindo nos termos do Capítulo VII da Carta das Nações Unidas, o encaminhamento ao Tribunal de casos que envolvam a prática de crimes sob a jurisdição deste último. Mesmo nesta situação excepcional, não basta que os crimes denunciados pelo Conselho sejam da competência do TPI, os mesmos também não poderão ter sido cometidos antes de $01 / 07 / 2002$, pois o Tribunal “[...] é uma criatura do Estatuto, e não do Conselho de Segurança e, embora as resoluções do Conselho possam prevalecer sobre as obrigações dos Estados em matéria de tratados (Art. 103 da Carta), não podem alterar os poderes de uma organização independente." ${ }^{18}$ (CRYER; FRIMAN; ROBINSON; WILMSHURST, 2007, p.138, nota de rodapé 98).

\section{Análise da Competência do TPI no caso do ataque ao Hospital de Kunduz por ForÇas Americanas}

O Centro de Trauma localizado na cidade de Kunduz, no Afeganistão foi aberto em 2011 pela Organização Internacional Não-governamental dos Médicos Sem Fronteiras (MSF). Referido hospital oferecia tratamento gratuito e de alta qualidade a seus pacientes, vítimas de traumas em geral. Esta era a única instalação na região nordeste do Afeganistão que oferecia este tipo de tratamento, sendo que, desde sua inauguração, mais de quinze mil cirurgias foram realizadas e mais de sessenta e oito mil pacientes em estado de emergência foram tratados (MSF, 2015).

No dia 28/09/2015, forças do Talibã invadiram a cidade de Kunduz, dando início a um combate armado com as forças do governo Afegão. Tendo em vista o aumento da intensidade do conflito instaurado, os MSF, no dia 29/09/2015, confirmaram com as respectivas partes envolvidas nas hostilidades - incluindo o Departamento de Defesa dos Estados Unidos e o exército Americano em Cabul, uma vez que este país prestava auxílio às forças governamentais Afegãs - a já muito bem conhecida localização do hospital, através do envio

18 Tradução nossa. 
das coordenadas de GPS exatas da mesma. O Departamento de Defesa e exército Americanos, bem como o Ministro do Interior e Defesa do Afeganistão, acusaram o recebimento da localização de referido Centro de Trauma (MSF, 2015).

Mesmo assim, na madrugada do dia 03/10/2015, foi autorizado pelos Estados Unidos um ataque na localidade exata onde se encontrava o Hospital de Kunduz. Por mais de uma hora, durante a qual os MSF emitiram vários avisos que o local estava sob ataque, o hospital foi bombardeado pelo avião americano AC-130U, deixando quarenta e dois mortos e trinta e sete feridos ${ }^{19}$. No momento do ataque, cento e cinco pacientes se encontravam no hospital, e duas, das três salas de operação, estavam sendo utilizadas. Sobreviventes relatam que pacientes queimaram em suas camas e integrantes da equipe médica tiveram seus membros amputados durante o bombardeio (MSF, 2015).

Nos primeiros relatórios após o incidente, foi indicado que o ataque aéreo havia sido requisitado por forças Americanas que estavam sendo ameaçadas por combatentes do Talibã em solo. No entanto, em entrevista concedida à imprensa no dia $05 / 10 / 2015$, o então Comandante da Missão de Apoio Resoluto e das Forças dos Estados Unidos no Afeganistão, General John Francis Campbell, afirmou que, diferentemente dos relatórios iniciais, foram forças Afegãs que haviam solicitado apoio aéreo Americano, o que resultou na destruição do hospital (EUA, 2015).

No dia 06/10/2015, o General Campbell prestou novos esclarecimentos, afirmando que a decisão em fornecer apoio aéreo havia sido uma decisão dos Estados Unidos, realizada dentro de sua cadeia de comando, sendo que o hospital tinha sido atingido por acidente em decorrência de referido apoio ${ }^{20}$. Uma investigação, conduzida por militares Americanos, foi aprovada em 21/11/2015 pelo General Campbell para apurar o incidente (EUA, 2016), porém, uma investigação independente foi demanda pelos MSF à Comissão Humanitária Internacional para a Apuração de Fatos ${ }^{21}$, uma vez que acreditavam que o ocorrido tratava-se de um crime de

19 Dados obtidos no site http://kunduz.msf.org/.

20 Vídeo do esclarecimento prestado pelo General John Francis Campbell disponível em https://www.nytimes.com/2015/10/06/ world/asia/afghanistan-kunduz-doctors-without-borders-hospital. html.

21 Em inglês: "International Humanitarian Fact-Finding Commission". guerra (MSF, 2016).

Em abril de 2016, o Departamento de Defesa dos Estados Unidos liberou o sumário referente às conclusões das investigações sobre o incidente do Hospital de Kunduz. No documento, afirma-se que a tribulação do avião AC-130U, em apoio a forças Americanas e Afegãs em solo, cometeu um erro de identificação e acabou atingindo o hospital, sendo que, nem a tripulação, nem as forças em solo, estavam cientes de que a aeronave atirava numa instalação médica. Concluiu-se, assim, que o incidente foi causado por uma combinação de erros humanos, agravados por falhas no processo e equipamento. Ademais, concluiu-se que o pessoal envolvido falhou em cumprir com as regras de engajamento e com a lei de conflitos armados, mas que, tais falhas, não constituíam um crime de guerra, uma vez que as condutas não tinham sido intencionais (EUA, 2016).

Por fim, a investigação identificou dezesseis membros do serviço Americano, cujas condutas ensejaram a tomada de ações disciplinares ou administrativas. Destes, doze foram punidos através das seguintes ações: suspensão e remoção da posição de comando, cartas de reprimenda, aconselhamento formal e, novo treinamento extensivo. Segundo o documento, medidas também foram tomadas para melhorar as operações militares no Afeganistão como, por exemplo, a realização de treinamento suplementar para as tropas e a revisão dos equipamentos utilizados nas operações. Ademais, foram aprovados pelo Departamento de Defesa a quantia de cinco milhões e setecentos mil dólares para a reconstrução do hospital, além do pagamento de indenizações a mais de cento e setenta indivíduos e suas famílias afetados pelo incidente (EUA, 2016).

Parte-se, neste momento, para a análise da competência do TPI para conhecer, processar e julgar o presente caso. Referida análise será conduzida com base nas informações já apresentadas anteriormente neste estudo.

\subsection{Competências ratione personae, ratione temporis e ratione loci}

Conforme visto, nenhuma qualidade pessoal influi na competência do TPI para julgar indivíduos maiores de idade, que venham a praticar alguma das condutas elencadas no artigo $5^{\circ}$ do Estatuto de Roma (ONU, 1998). Assim, a competência ratione personae não desper- 
ta maiores controvérsias, podendo os perpetradores do ataque ao Hospital de Kunduz serem processados pelo Tribunal.

A conduta em análise ocorreu em 03/10/2015, na cidade de Kunduz, localizada no Afeganistão, que ratificou o Estatuto de Roma na data de 10/02/200322. Portanto, a ação que causou o incidente foi posterior à entrada em vigor do Estatuto para o Afeganistão, possuindo o TPI competência ratione temporis em relação ao caso. Já a competência em razão do lugar, naquilo que preconiza o artigo 12, 2, “a” do Estatuto (ONU, 1998), encontra-se também satisfeita para que o Tribunal possa exercer sua jurisdição, uma vez que a conduta foi perpetrada no território de um Estado-parte.

Porém, no que tange a esta última competência, existe dois pontos que merecem uma análise mais aprofundada: aquele que diz respeito ao Princípio da Complementaridade, presente no artigo 17 do Estatuto de Roma (ONU 1998), e ao ne bis in idem (dupla punição), preconizado no artigo 20 de dito Estatuto. Neste sentido:

Sob a rubrica de "admissibilidade", no Artigo 17, o Estatuto endereça a complexa relação entre os sistemas legais nacionais e o Tribunal Penal Internacional. O Tribunal é obrigado a considerar um caso inadmissível, quando este está sendo lidado apropriadamente por um sistema nacional de justiça. $[\ldots]$

O Artigo 17 (1) declara que um caso é inadmissível quando está sendo investigado ou processado por um Estado que possui jurisdição sobre o mesmo, ou quando o caso já tenha sido investigado e o Estado decidiu por não processá-lo. Nestas circunstancias, o Tribunal somente poderá proceder quando o Estado "não tiver vontade ou ter incapacidade real" de investigar ou processar o caso. [...]

A questão da falta de vontade surgirá quando um sistema nacional de justiça está "realizando os procedimentos" para fazer parecer que a investigação e o processo estão em andamento, apesar de faltar a vontade de fazê-lo, ou até mesmo permitir um falso julgamento, para que em qualquer procedimento subsequente o acusado possa alegar que já foi julgado e condenado, e que qualquer novo julgamento está impedido pela aplicação da regra contra a dupla punição. O Estatuto requer que o Tribunal avalie essas questões "levando em consideração os princípios do devido processo reconhecido pelo direito internacional", sugerindo uma avaliação da qualidade da justiça do ponto de vista da equidade processual, talvez até mesmo

22 Informações obtidas no site: https://asp.icc-cpi.int/en_menus/asp/states $\% 20$ parties/asian $\% 20$ states/Pages/afghanistan.aspx. substantiva. [...]

Quando um caso já foi julgado por um sistema de justiça doméstico, o artigo da complementaridade no Estatuto aponta para outra disposição, a proibição da dupla punição ou ne bis in idem, estabelecida no Artigo 20 e codificada em importantes tratados de direitos humanos como o Pacto Internacional sobre os Direitos Civis e Políticos. O teste para avaliar se os procedimentos do julgamento nacional foram legítimos difere um pouco do padrão "incapaz ou sem vontade real" presente no Artigo 17, que se aplica às investigações pendentes ou concluídas e aos processos pendentes. Se um julgamento interno já foi concluído, o mesmo é um impedimento ao processamento pelo Tribunal, exceto no caso de procedimentos fraudulentos. Estes são definidos como julgamentos realizados para proteger um ofensor da responsabilidade criminal, ou que, de outro modo, não foram conduzidos com independência ou imparcialidade, sendo realizados de uma maneira que "dada as circunstâncias, seja incompatível com a intenção de levar a pessoa em causa perante a justiça”. ${ }^{23}$ (SCHABAS, 2004, p.8588).

Pois bem, diante do Princípio da Complementaridade, tanto o Afeganistão, local onde ocorreu a conduta, como os Estados Unidos, cujos nacionais perpetraram a conduta, possuem jurisdição primária, estando o exercício da competência do TPI, num primeiro momento, reservada à ocorrência das circunstâncias excepcionais descritas pelo artigo 17 do Estatuto de Roma (ONU, 1998). No tocante ao Afeganistão, o presidente Ashraf Ghani Ahmadzai estabeleceu uma comissão composta por cinco investigadores para apurar as circunstâncias que levaram à captura da cidade de Kunduz pelo Talibã, bem como para analisar o ataque Americano ao Hospital de Kunduz. Referida comissão apuradora, liderada pelo ex-chefe da agência de inteligência nacional Afegã, Amrullah Saleh, tinha a missão de entregar um relatório ao presidente esclarecendo o que ocorrera em Kunduz, as reformas que deveriam ser feitas, bem como as lições aprendidas para o futuro ${ }^{24}$. No entanto, a comissão acabou excluindo o ataque ao Hospital de Kunduz de suas investigações (JEONG, 2016). Assim, percebe-se a falta de vontade de tal país em investigar, processar e julgar o caso.

Em relação aos Estados Unidos conforme visto, o caso foi conduzido por militares Americanos, sendo que dezesseis pessoas, cujas identidades sequer foram

23 Tradução nossa.

24 Informações disponíveis no site: http://www.usnews.com/ news/world/articles/2015/10/10/afghan-president-appoints-investigators-for-kunduz-airstrike. 
divulgadas, foram investigadas e, destas, doze foram "punidas" administrativamente, uma vez que se alegou a ausência de intenção na conduta. Pode-se afirmar, sem nenhuma dúvida, que esta situação encaixa-se com perfeição nas hipóteses excepcionais descritas no artigo 17, 2, "a" e "c" do Estatuto de Roma (ONU, 1998), pelos seguintes fatos: 1) o incidente foi investigado, processado e julgado por uma comissão liderada por militares Americanos, o que levanta suspeitas sobre a independência e imparcialidade da investigação; 2) apesar da a gravidade do incidente, bem como o fato de existirem vários indícios apontando para um crime, foi concluído na investigação dos Estados Unidos que o ocorrido não se tratava de crime de guerra por não ter havido intenção na conduta dos agentes, sendo estes punidos administrativamente. Não se questiona, sobre este ponto, a falta de um processo criminal em si, pois uma decisão administrativa, dependendo das circunstâncias, pode ser plenamente válida para afastar a competência do TPI, o que, evidentemente, não é o caso do ataque ao Hospital de Kunduz. A grave negligência, como se verá mais à frente no presente estudo, também é punível, não precisando existir, necessariamente, a intenção, o que por si só já demandaria uma investigação judicial, devido à complexidade das circunstâncias presentes; 3 ) várias circunstâncias e informações-chave envolvendo o ataque ao Hospital de Kunduz, não foram devidamente esclarecidas ou divulgadas, o que levanta suspeitas sobre a decisão administrativa ter sido proferida para proteger os perpetradores de sua responsabilidade criminal. Por exemplo: o fato de que, durante todo o ataque, os MSF alertaram as partes que estavam sendo atingidos e, mesmo assim, o bombardeio continuou a ocorrer por cerca de uma hora; o sigilo das gravações contendo a conversa entre a tripulação do avião AC-130U e as tropas Americanas em solo, nas quais há indícios do questionamento da legalidade da ordem de ataque pela tripulação ${ }^{25}$; o sigilo sobre a identidade dos militares punidos, o que impossibilita averiguar se referidas punições verdadeiramente existiram e, em caso positivo, se estão sendo cumpridas.

Assim, perante o exposto, a investigação promovida pelos Estados Unidos no caso do ataque ao Hospital de Kunduz, falha em cumprir com os requisitos da independência e da imparcialidade, tendo sido o processo

25 Informações disponíveis no site: http://www.slate.com/ blogs/the_slatest/2015/10/16/kunduz_hospital_bombing the_u_s_airstrike_is_looking_more_and_more_like.html. administrativo conduzido de uma maneira que, dada as circunstâncias, foi inteiramente incompatível com a intenção de levar os perpetradores perante a justiça. Somado a isto, a extrema brandura da punição, frente à imensa gravidade do caso, aponta, inevitavelmente, para a intenção em se subtrair os agentes de suas devidas responsabilidades criminais frente ao TPI. Portanto, duas exceções do artigo 17 do Estatuto de Roma (ONU, 1998) encontram-se presentes, justificando a jurisdição do Tribunal para conhecer, processar e julgar o presente caso.

\subsection{Competência ratione materiae}

Para se definir a competência ratione materiae em relação à conduta praticada pelos militares Americanos, primeiramente é necessário que se determine qual a natureza do conflito armado, dentro do qual a mesma ocorreu. A guerra internacional travada no Afeganistão pelos Estados Unidos foi formalmente encerrada em 28/12/2014. Porém, forças militares Americanas permaneceram no país em apoio ao governo Afegão, para auxiliá-lo em sua luta contra o Talibã. Esta é uma situação que não se encaixa nos conceitos clássicos de conflito armado internacional e interno. Ou seja, trata-se de um cenário que se encaixa na noção moderna de conflitos armados híbridos ou mistos. Porém, com base na jurisprudência do caso Dusko Tadic (Caso no IT-94-1), já citada anteriormente neste estudo, um conflito interno tornar-se-á internacional, caso outro Estado intervenha no mesmo através de suas tropas (TPII, 1999, p.34, parágrafo 84$)$.

Desta forma, pode-se afirmar que o ataque ao Hospital de Kunduz ocorreu no contexto de um conflito armado internacional. Analisando-se o artigo $8^{\circ}$ do Estatuto de Roma (ONU, 1998), é possível encontrar dois crimes de guerra internacional que se encaixam na conduta perpetrada pelos soldados Americanos: a do artigo $8^{\circ}, 2$, "b", iv e ix.

O primeiro crime, descrito no item iv, diz respeito à conduta de lançar intencionalmente um ataque, sabendo que o mesmo causará perdas acidentais de vidas humanas ou ferimentos na população civil, bem como danos em bens de caráter civil, que se revelem claramente excessivos em relação à vantagem militar global concreta e direta que se previa. Neste caso, a previsão legal tem como objetivo proteger a vida, integridade fí- 
sica e os bens da população civil.

O segundo crime, descrito no item ix, trata sobre o direcionamento intencional de ataque a edifícios consagrados ao culto religioso, à educação, às artes, às ciências ou à beneficência, monumentos históricos, hospitais e lugares onde se agrupem doentes e feridos, sempre que não se trate de objetivos militares. Aqui, o objetivo da norma é proteger locais específicos considerados importantes.

A conduta dos militares Americanos, além de ter sido direcionada a um local protegido pelo Direito $\mathrm{Hu}-$ manitário, qual seja, um hospital (item ix), também matou quarenta e duas pessoas e deixou trinta e sete feridas (item iv). Ou seja, apesar da conduta ter sido única, houveram dois resultados materiais, descritos em normas distintas sob o Estatuto de Roma. Cabe aqui, porém, um importante esclarecimento sobre os elementos dos crimes de guerra, mais especificamente no que diz respeito ao elemento mental da ação criminosa ou mens rea.

Ambas os crimes descritos exigem que haja a intenção do agente em praticar as condutas que os definem. Este, aliás, foi o principal argumento presente na investigação dos Estados Unidos para afastar a responsabilidade criminal de seus nacionais, qual seja, que o ataque não foi intencional. No entanto, esta alegação não é suficiente para eximir os agentes de sua responsabilidade no caso em análise, uma vez que houve, no mínimo, dolo direto de segundo grau na conduta dos mesmos.

O artigo 30 do Estatuto de Roma prega que, salvo disposição em contrário, “[...] nenhuma pessoa poderá ser criminalmente responsável e punida por um crime da competência do Tribunal, a menos que atue com vontade de o cometer e conhecimento dos seus elementos materiais" (ONU, 1998). Assim, como regra geral, um crime sob o Estatuto deve ser cometido tanto com intenção, como com conhecimento do indivíduo. A Câmara de Pré-Julgamento II do TPI já se pronunciou sobre este tema no caso Jean-Pierre Bemba Gombo (Caso n: ICC-01/05-01/08), em decisão datada de 15/06/2009, na qual afirmou que:

[...] os termos "intento" e "conhecimento", conforme mencionado no artigo 30(2) e (3) do Estatuto, reflete o conceito de dolus, o qual requer a existência tanto de um elemento volitivo, como um cognitivo. Geralmente, o dolus pode tomar uma de três formas, dependendo da força do elemento volitivo vis-à-vis ao elemento cognitivo - a saber, (1) dolus directus de primeiro grau ou intento direto, (2) dolus directus de segundo grau - também conhecido como intenção oblíqua, e (3) dolus eventualis - comumente referido como imprudência subjetiva ou advertida.

Na visão da Câmara, o artigo 30(2) e (3) do Estatuto abarca dois graus de dolus. $\mathrm{O}$ dolus directus de primeiro grau (intento direto) requer que o suspeito saiba que suas ações ou omissões produzirão os elementos materiais do crime, e que as execute com a vontade proposital (intento) ou desejo de produzir referidos elementos materiais do crime. De acordo com o dolus directus de primeiro grau, o elemento volitivo é prevalente, uma vez que o suspeito, propositalmente, tem vontade ou deseja obter o resultado proibido.

$\mathrm{O}$ dolus directus de segundo grau não requer que o suspeito tenha o real intento ou vontade de concretizar os elementos materiais do crime, e sim que o mesmo esteja ciente que tais elementos serão o resultado quase que inevitável de suas ações ou omissões [...]. Neste contexto, o elemento volitivo diminui substancialmente, sendo sobrepujado pelo elemento cognitivo, i.e. a consciência de que suas ações irão causar a consequência proibida indesejada. ${ }^{26}$ (TPI, 2009, p.120/121, parágrafos 357359).

Através da análise dos fatos que envolveram o ataque ao Hospital de Kunduz, pode-se afirmar que, se realmente não houve dolo direito de primeiro grau (intenção direta) na conduta, conforme supostamente alegado na investigação dos Estados Unidos, pelo menos o dolo direto de segundo grau esteve presente. Conforme visto, nesta espécie de dolo direto (intenção oblíqua), não há a necessidade que exista uma intenção real ou vontade do agente em concretizar o resultado material do crime, basta a ciência de que sua ação causará, quase que inevitavelmente, tal resultado. Ou seja, há uma diminuição considerável do elemento volitivo, dando espaço ao elemento cognitivo.

É inegável que, no mínimo, houve intenção oblíqua dos agentes, pelos seguintes fatos: 1) os militares sabiam a exata localização, através de coordenadas de GPS, do hospital, que fora fornecida dias antes do ataque; 2) como medida de precaução, duas bandeiras dos MSF foram colocadas no teto do hospital, além daquela já presente em sua entrada (MSF, 2015), aumentando-se as formas de identificação de referida instalação médica; 3) os avisos emitidos pelos MSF durante o ataque para alertar que o hospital estava sendo atingido.

Seja qual for a verdadeira intenção por trás da conduta dos agentes, somente pelas circunstâncias aqui enumeradas, já é possível afirmar o conhecimento de que as ações perpetradas concretizariam os resultados

26 Tradução nossa. 
matérias de ambos os crimes de guerra aqui aduzidos. Esclarecido este importante ponto, volta-se à análise dos crimes de guerra cometidos pelos militares Americanos.

O fato que deu origem ao ataque no Hospital de Kunduz foi a requisição de apoio por tropas Afegãs em solo contra forças do Talibã. Não é nenhum segredo que vários combatentes Talibãs estavam sendo tratados em referido hospital. No entanto, é fato que os mesmos não estavam se utilizando de dita instalação médica como base ou local de resistência armada, conforme foi alegado por autoridades do Afeganistão, logo após o incidente, como forma de justificar o ataque (JEONG, 2016). Eles lá estavam pois foram feridos em combate e precisavam de atendimento médico urgente.

Além disso, no dia 01/10/2015, os MSF foram questionados por um oficial Americano localizado em Washington, se o hospital contava com um grande número de Talibãs escondidos em seu interior. Referida Organização Internacional respondeu que, dentre os pacientes que se encontravam sob seus cuidados médicos, haviam sim combatentes ligados ao Talibã (MSF, 2015), fato este que, por si só, não transforma automaticamente o hospital - um local internacionalmente protegido por lei - num alvo militar válido.

Por se tratar de uma organização neutra, os MSF não questionam a qual parte das hostilidades seus pacientes pertencem, uma vez que isto não é uma informação relevante do ponto de vista médico (MSF, 2015). Ou seja, eles se encontravam ali para prestar seus serviços para qualquer indivíduo que deles necessitassem, fossem eles combatentes Afegãos, Americanos ou ligados ao Talibã.

Portanto, pelo conjunto de informações que envolvem o incidente, conclui-se que tropas Afegãs solicitaram apoio militar Americano, para atacar um local, no caso o hospital, que alegavam estar sob controle do Talibã, servindo como base e refúgio para seus combatentes. Com isto em mente, é possível analisar mais a fundo os crimes de guerra perpetrados.

\subsubsection{Artigo 8०, 2, "b", iv do Estatuto de Roma}

A vantagem ou objetivo militar buscado no ataque ao Hospital de Kunduz era a destruição de um local que, supostamente, abrigava combatentes Talibãs, servindo de base para os mesmos. Na busca deste objetivo, várias vidas foram perdidas, civis foram feridos, e uma instalação médica de importância ímpar na região foi completamente destruída. O que irá dizer se este resultado constituiu-se em algo flagrantemente excessivo ao objetivo militar almejado, será o Princípio da Proporcionalidade, de observância obrigatória em qualquer conflito armado. Assim, antes de se executar qualquer investida, as partes de um conflito armado devem ponderar se os meios utilizados, bem como se os objetivos a serem alcançados, são proporcionais e justificáveis em relação ao dano colateral que seu ataque causará. Neste sentido, Francisco de Vitoria afirma que:

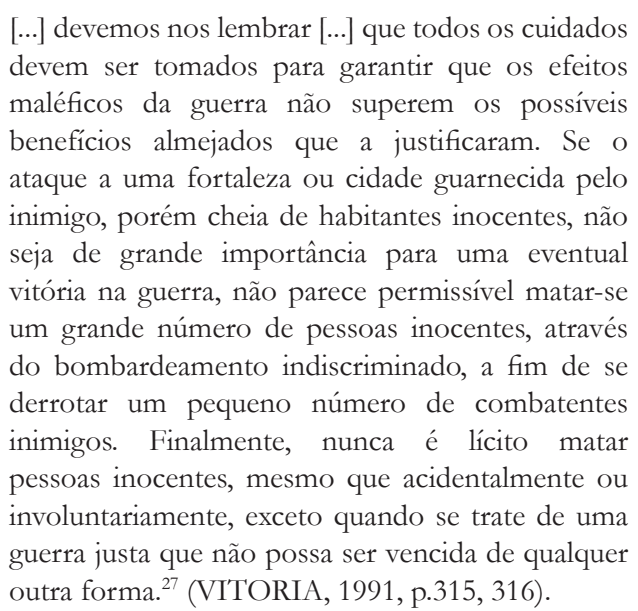

Não se irá discutir aqui a proporcionalidade em relação ao jus ad bellum, ou seja, se a guerra dentro da qual o incidente de Kunduz ocorreu é considerada justa ou injusta, uma vez que este não é o foco do presente trabalho. O que importa do texto supracitado é a ideia de proporcionalidade no travamento da guerra (jus in bello). Vê-se que, para Francisco de Vitoria, a morte acidental de inocentes somente é aceitável, quando a vantagem militar for decisiva para uma vitória na guerra e não exista qualquer outra forma de se vencê-la. Ou seja, são dois requisitos que devem ser observados pelas partes nas hostilidades.

Indaga-se, portanto, se bombardear um hospital ativo era realmente a única estratégia existente no presente caso. $\mathrm{O}$ apoio deveria ter sido realizado por tropas em solo para, primeiramente, confirmar se realmente haviam forças Talibãs, armadas e prontas para o combate, dentro das instalações médicas. Como já salientado, os poucos combatentes Talibãs que se encontravam no local estavam destituídos de armas, e até mesmo de vestes ou adornos que os identificassem como tais, justamente para que se evitasse qualquer tipo de tensão dentro do

27 Tradução nossa. 
hospital. Justamente por estarem recebendo tratamento médico, se encontravam, ainda que temporariamente, fora de combate, não representando qualquer ameaça imediata às partes contrárias no conflito.

Assim, no presente caso, não se consegue visualizar sequer a existência de um objetivo militar propriamente dito, quanto mais uma vantagem militar que justificasse a prática de um ato tão hediondo. Por todo exposto, conclui-se que os perpetradores do ataque ao Hospital de Kunduz praticaram o crime de guerra descrito no artigo 8, 2, "b", iv do Estatuto de Roma (ONU, 1998).

\subsubsection{Artigo 8०, 2, “b”, ix do Estatuto de Roma}

Através de uma interpretação a contrario sensu do crime de guerra descrito no artigo 8', 2, "b", ix do Estatuto de Roma (ONU, 1998), somente seria lícito atacar os lugares protegidos por referida norma, caso se constituíssem em objetivos militares. Ocorre que, mesmo que algo seja considerado por uma parte como um objetivo militar, ainda assim é necessário que se pondere se as vantagens a serem alcançadas justificam os danos que também irão resultar da conduta.

Portanto, não é qualquer objetivo militar que será capaz de justificar um ataque a um hospital ou escola, eximindo os indivíduos que o perpetraram de sua responsabilidade criminal. Conforme visto no tópico anterior, a vantagem a se conquistar deve ser tamanha a ponto de contribuir de forma decisiva para uma eventual vitória da guerra. Obviamente que, dependendo da situação, isto não se traduz numa tarefa fácil, mas, no caso concreto em análise, o curso de ação a se tomar era óbvio: não atacar, de forma indiscriminada, um hospital em atividade.

Não se consegue imaginar de que forma o bombardeio ao Hospital de Kunduz poderia proporcionar uma vantagem militar considerável ou ter contribuído de forma decisiva com a vitória sobre o Talibã. Assim, não resta outra conclusão a não ser considerar que referido hospital não se tratava de um objetivo militar válido, não estando os perpetradores do ataque livres de sua responsabilidade criminal.

\section{Considerações finais}

O TPI foi criado com o objetivo de acabar com a impunidade dos indivíduos que cometem os crimes mais graves que afetam a comunidade internacional como um todo. Sendo assim, quando crimes de guerra, como o ataque ao hospital de Kunduz, são cometidos, toda a humanidade é afetada, exigindo uma resposta adequada em relação aos perpetradores da conduta proibida. Porém, em respeito à complementaridade, aos Estados que possuam jurisdição sobre o caso, é dada a primazia de lidar com o mesmo antes que o TPI possa exercer sua jurisdição, desde que os procedimentos sejam conduzidos de forma séria e justa, para se evitar que os criminosos sejam isentos, injustificadamente, de sua responsabilidade criminal.

Assim, o mínimo que se poderia esperar da investigação promovida pelos Estados Unidos, era que a mesma se pautasse na transparência e na imparcialidade, uma vez que, o crime perpetrado pelos nacionais daquele país, não concernem somente a eles ou ao Estado onde a conduta foi praticada, e sim a comunidade internacional como um todo.

Infelizmente, não foi com base na transparência e na imparcialidade que tal investigação foi conduzida. A mesma se mostra muito genérica e carece de provas que corroborem todo o alegado em favor da isenção da responsabilidade criminal dos militares envolvidos no incidente. Por exemplo, a conversa gravada entre a tripulação do avião AC-130U e as tropas em solo, que poderia provar cabalmente a inocência ou a culpa dos militares Americanos, não foi divulgada. E neste caso, acredita-se que o sigilo não se justifica, primeiramente porque, como já dito, o crime cometido concerne a toda comunidade internacional, que merece uma resposta adequada ao crime perpetrado e, em segundo lugar, duvida-se que um diálogo de poucas horas, gravado nestas circunstâncias, possa comprometer algum segredo de Estado que justifique o sigilo. Portanto, esta atitude evidencia a falta de seriedade através da qual foi realizada dita investigação, o que levanta suspeitas mais do que suficientes para a abertura de uma investigação independente e imparcial pelo TPI.

Por todas as informações e evidências aqui trazidas, pela gravidade do caso em questão, bem como pelos fundamentos apresentados em relação ao cometimento, pelos militares Americanos, dos crimes estabelecidos no 
artigo $8^{\circ}, 2$, "b", iv e ix do Estatuto de Roma (ONU, 1998), acredita-se, fortemente, que o Procurador do TPI possua fundamentos suficientes para apresentar um pedido de autorização, perante o Juízo de Instrução, para a abertura de um inquérito sobre o incidente ocorrido Kunduz.

O ataque ao Hospital de Kunduz não se resume às vítimas imediatas, mortas e feridas durante o ataque, mas engloba milhares de outros indivíduos que têm deixado de receber atendimento médico gratuito e especializado, desde a destruição de referida instalação médica. Desta forma, considera-se que a instauração de um inquérito pelo TPI é uma medida essencial a ser tomada, para que este crime de guerra, de consequências nefastas, não fique impune. Ademais, referida medida reafirmaria a força, seriedade, imparcialidade e comprometimento do TPI, consolidando, ainda mais, a sua presença e excepcional importância perante a comunidade internacional.

\section{REFERÊNCIAS}

AKANDE, Dapo. Classification of Armed Conflicts: Relevant Legal Concepts. In: WILMSHURST, Elizabeth (org.). International Law and the Classification of Conficts. Oxford: University of Oxford, 2012.

BARTELS, Rogier. Timelines, borderlines and conflicts. The historical evolution of the legal divide between international and non-international armed conflicts. In: International Review of the Red Cross. Genebra: Comitê Internacional da Cruz Vermelha, 2009, v.91, n.873, pp.35-67.

BENZING, Markus. U.S. Bilateral Non-Surrender Agreements and Article 98 of the Statute of the International Criminal Court: An Exercise in the Law of Treaties. In: BOGDANDY, Armin von; WOLFRUM, Rüdiger (orgs.). Max Planck Yearbook of United Nations Law. Leiden: Koninklijke Brill, 2004, v.8, pp.181-236.

CONSELHO EUROPEU (CE). 2450 ${ }^{a}$ Sessão do Conselho Europeu, datada de 30/09/2002. Disponível em https://www.consilium.europa.eu/uedocs/ cmsUpload/12134_02en.pdf. Acesso dia 21/01/2017.

CRAWFORD, Emily. Unequal before the law: Questioning the distinction between types of armed conflict in international law. Tese submetida à Faculdade de Direito da Universidade de New South Wales, como requisito para a obtenção do título de Doutor em Filosofia. Sydney: University of New South Wales, 2008.

CRAWFORD, James; SANDS, Philippe; WILDE, Ralph. Joint Opinion in the matter of the Statute of the International Criminal Court and in the matter of Bilateral Agreements sought by the United States under Article 98(2) of the Statute. Disponível em http://www.amicc.org/docs/Art9814une03FINAL.pdf. Acesso dia 21/01/2017.

CRYER, Robert; FRIMAN, Hakan; ROBINSON, Darryl; WILMSHURST, Elizabeth. An Introduction to International Criminal Law and Procedure. Cambridge: Cambridge University Press, 2007.

DIAS, Maria Tereza Fonseca; GUSTIN, Miracy Barbosa de Sousa. (Re)Pensando a Pesquisa Jurídica: Teoria e Prática. $4^{\mathrm{a}}$ Ed. Belo Horizonte: Del Rey, 2013.

DÖRMANN, Knut. War Crimes under the Rome Statute of the International Criminal Court, with a Special Focus on the Negotiations on the Elements of Crimes. In: BOGDANDY, Armin von; WOLFRUM, Rüdiger (orgs.). Max Planck Yearbook of United Nations Law. Leiden: Koninklijke Brill, 2003, v.7, pp.341-407.

ESTADOS UNIDOS DA AMÉRICA (EUA) (2015). Department of Defense Press Briefing by Gen. Campbell in the Pentagon Briefing Room (05/10/2015). Disponível em https://www.defense.gov/News/Transcripts/Transcript-View/Article/621848/department-of-defensepress-briefing-by-gen-campbell-in-the-pentagon-briefing-r. Acesso dia 28/01/2017.

(2016). SUBJECT: Summary of the Airstrike on the MSF Trauma Center in Kundur, Afghanistan on October 3, 2015; Investigation and Follow-on Actions (29/04/2016). Disponível em https://seelaikarzai.files.wordpress. com/2016/05/00-centcom-summary-memo.pdf. Acesso dia $28 / 01 / 2017$.

HEBEL, Herman von; ROBINSON, Darryl. Crimes Within the Jurisdiction of the Court. In: LEE, Roy (org.). The International Criminal Court: The Making of the Rome Statute, Issues, Negotiations, Results. Haia: Kluwer Law International, 1999.

HWANG, Phylilis. Defining Crimes Against Humanity in the Rome Statute of the International Criminal Court. In: Fordham International Law Journal. Berkeley: The Berkeley Electronic Press, 1998, v.22, pp.457-504.

JEONG, May. Death from the Sky: Searching for Ground Truth in the Kundur. Hospital Bombing. Disponível em 
https:/ theintercept.com/2016/04/28/searching-forground-truth-in-the-kunduz-hospital-bombing/. Acesso dia 30/01/2017.

LIMA, Renata Mantovani de. Tribunais Híbridos e Justiça Internacional Penal. Belo Horizonte: Arraes Editores, 2012.

LIMA, Renata Mantovani de; BRINA, Marina Martins da Costa. O Tribunal Penal Internacional. Belo Horizonte: Editora Del Rey, 2006.

MAZZUOLI, Valerio de Oliveira. Curso de Direito Internacional Público. 9ª Ed. São Paulo: RT, 2015.

MÉDICOS SEM FRONTEIRAS (MSF). Public release of initial MSF internal review (05/11/2015). Disponível em http://kunduz.msf.org/pdf/20151030_kunduz_review_EN.pdf. Acesso dia 27/01/2017.

MÉGRET, Frédéric. Epilogue to an Endless Debate: The International Criminal Court's Third Party Jurisdiction and the Looming Revolution of International Law. In: The European Journal of International Law. Oxford: Oxford University Press, 2001, v.12, n.2, pp.247268.

ORDEMATT, Jed. Between Law and Reality: 'New Wars' and Internationalised Armed Conflict. In: Amsterdam Law Forum. Amsterdam: VU University Amsterdam, 2013, v.5.

ORGANIZAÇÃO DAS NAÇÕES UNIDAS (ONU) (1969). Convenção de Viena sobre o Direito dos Tratados. Disponível em http://www.planalto.gov.br/ccivil_03/_ ato2007-2010/2009/decreto/d7030.htm. Acesso dia $22 / 01 / 2017$.

ORGANIZAÇÃO DAS NAÇÕES UNIDAS (ONU) (1998). Estatuto de Roma. Disponível em https://www. planalto.gov.br/ccivil_03/decreto/2002/d4388.htm. Acesso dia 21/12/2016.

(1997). Preparatory Committee on the establishment of an International Criminal Court: Decisions taken by the Preparatory Committee at its session held from 1 to 12 December 1997. Disponível em http:/ /www.legal-tools.org/ en/doc/787a4d/. Acesso dia 29/12/2016.

ROBINSON, Darryl. Defining "Crimes Against Humanity" at the Rome Conference. In: The American Journal of International Law. Washington: American Society of International Law, 1999, v.93, n.1, pp.43-57.

SCHABAS, Willian Anthony. An Introduction to the In- ternational Criminal Court. $2^{\mathrm{a}}$ Ed. Cambridge: Cambridge University Press, 2004.

SIVAKUMARAN, Sandesh. Re-envisaging the International Law of Internal Armed Conflict. In: The European Journal of International Law. Oxford: Oxford University Press, 2011, v.22, n.1, pp.219-264.

TAN JUNIOR, Chet. The Proliferation of Bilateral Non-Surrender Agreements Among Non-Ratifiers of the Rome Statute of the International Criminal Court. In: The American University International Law Review. Washington: Digital Commons, 2003, v.19, n.5, pp.11151180.

TRIBUNAL PENAL INTERNACIONAL (TPI) (2011). Elements of Crimes. Disponível em https://www. icc-cpi.int/NR/rdonlyres/336923D8-A6AD-40ECAD7B-45BF9DE73D56/0/ElementsOfCrimesEng. pdf. Acesso dia 28/12/2016.

(2009). Procurador v. Jean-Pierre Bemba Gombo (ICC-01/05-01/08) - Decisão da Câmera de Pré-Julgamento II datada de 15/06/2009. Disponível em https://www.icc-cpi.int/Pages/record. aspx?docNo=ICC-01/05-01/08-424. Acesso dia 02/02/2017.

TRIBUNAL PENAL INTERNACIONAL PARA A EX-IUGOSLÁvIA (TPII). Procurador v. Dusko Tadic (IT-94-1) - Julgamento da Câmera de Apelação datado de 15/07/1999. Disponível em http://www.icty.org/case/ tadic/. Acesso dia 04/01/2017.

VARELLA, Marcelo Dias. Direito Internacional Público. $6^{\mathrm{a}}$ Ed. São Paulo: Saraiva, 2016.

VERHOEVEN, Sten. International and Non-international Armed Conflicts. In: VERHOEVEN, Sten; WOUTERS, Jan (orgs.). Armed Conflicts and the Law. Lovaina: Institute for International Law, 2007, n.107.

VITORIA, Francisco de. De Jure Belli. Tradução em inglês: On the Law of War. In:

LAWRANCE, Jeremy; PADGEN, Anthony (orgs.). Cambridge Texts in the History of Political Thought: Political Writings. Cambridge: Cambridge University Press, 1991.

WAGNER, Markus. The ICC and its Jurisdiction Myths, Misperceptions and Realities. In: BOGDANDY, Armin von; WOLFRUM, Rüdiger (orgs.). Max Planck Yearbook of United Nations Law. Leiden: Koninklijke Brill, 2003, v.7, pp.409-512. 
WILLMOTT, Deidre. Removing the Distinction between International and Non-International Armed Con- flict in the Rome Statute of the International Criminal Court. In: Melbourne Journal of International Law. Melbourne: The University of Melbourne, 2004, v.5. 
Para publicar na Revista de Direito Internacional, acesse o endereço eletrônico www.rdi.uniceub.br ou www.brazilianjournal.org.

Observe as normas de publicação, para facilitar e agilizar o trabalho de edição. 